Fourth Scientific Meetring-Second Scottish Meetting

Department of Physiology, University College, Dundee, MAY $16 \mathrm{TH}, 1942$

\title{
FOOD SUPPLIES IN RELATION TO HUMAN NEEDS PART 2. REQUIREMENTS IN TERMS OF FOOD
}

\author{
Chairman, Mr. J. M. CAIE
}

\section{Translation of Standards into Terms of Foods}

\author{
Dr. I. Leitch (Imperial Bureau of Animal Nutrition, Bucksburn, \\ Aberdeen)
}

At the first Scottish scientific meeting, Sir John Orr (1944) discussed dietary standards in general and the other speakers dealt in detail with the latest standard, proposed by the U.S. National Research Council.* It was agreed that, within the limits of present knowledge, this standard appeared to be adequate. When the standards proposed by Stiebeling in $1933^{*}$ and by the League of Nations in $1935^{*}$ are compared with this new standard, on the basis of the allowances per head of the population (Table 1), it will be seen that there is no significant difference between

TABLE 1

Requirements per Head of Population: Theoretical Allowances

\begin{tabular}{|c|c|c|c|c|}
\hline & & $\begin{array}{l}\text { Stiebeling, } \\
1933,^{k} 1939^{1}\end{array}$ & $\begin{array}{l}\text { League of Nations, } \\
1935,{ }^{1} 1936,{ }^{1} 1937\end{array}$ & $\begin{array}{l}\text { N.R.C. } \\
\text { Standard }\end{array}$ \\
\hline \multirow{2}{*}{\multicolumn{2}{|c|}{$\begin{array}{l}\text { Energy requirement: net Calories } \\
\text { Per cent. of total calories from }\end{array}$}} & 2810 & 2980 & 2775 \\
\hline & & $9 \cdot 7$ & (12) & $9 \cdot 5$ \\
\hline Protein g. & $\ldots$ & 68 & (89) & 66 \\
\hline Calcium g. & $\ldots$ & 0.90 & $0.83(1937)^{2}$ & 0.91 \\
\hline Phosphorus g. & $\ldots$ & $1 \cdot 23$ & - & - \\
\hline Iron mg. & $\ldots$ & 13 to 14 & - & 12 \\
\hline Vitamin A I.U. & . & 5800 & $\begin{array}{l}2000-4000(1937) \\
\text { (or more) }\end{array}$ & 4696 \\
\hline Vitamin $B_{1}$ I.U. & . & 460 & $300(1937)$ & 516 \\
\hline Vitamin C, ascorbic a & $\mathrm{mg}$. & 71 & $30(1937)$ & 71 \\
\hline Ribotlavin $\quad \mathrm{mg}$. & $\cdots$ & $\mathrm{I} \cdot 74$ & - & $2 \cdot 3$ \\
\hline Nicotinic acid mg. & .. & - & - & $15 \cdot 5$ \\
\hline Vitamin D I.U. & $\ldots$ & - & 一 & approx. $210^{3}$ \\
\hline
\end{tabular}

${ }^{1}$ Cf. footnote to $\mathrm{p} .60$.

2 Minimum standards: $c f$. Analysis of Diet, Table 3.

3 The National Research Council allows also 400 to 800 I.U. vitamin D for the latter half of pregnancy, for the nursing mother and for children under 1 year. In the absence of sunshine, amounts up to 400 I.U. should probably be provided for older children and adults also.

them. There is, therefore, an agreed theoretical standard which can be used as a basis in planning.

* References are given in the paper by Orr (1944). Cf. also footnote to p. 43. 
When translating these standards into terms of foods, it is important to know whether the intention is that the standards should be taken literally. The question was raised at the first meeting of the man doing hard work, allowed 4500 Calories and $70 \mathrm{~g}$. protein by the N.R.C. standard. It would be difficult to plan palatable diets on such a basis. The proportion of the energy from protein would be only 6.4 per cent. If the foods which make up normal diets in common use are examined (Table 2)

TABLE 2

Specified Constitumins m Foods Compared with Average Allowances Per 100 Calories, Calculated from N.R.C. Standards

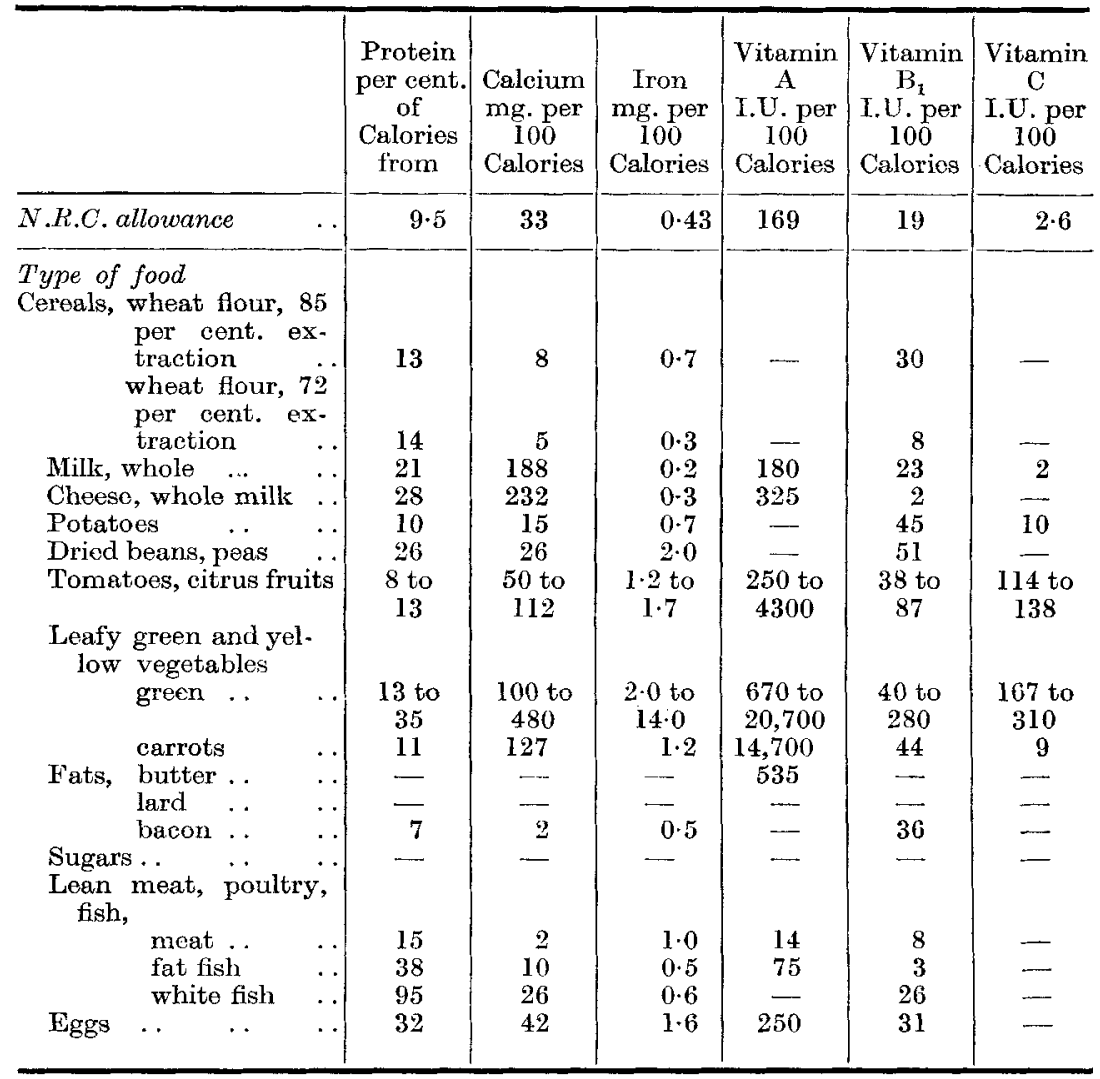

it is seen that the percentage of energy derived from protein is for bread cereals about 13 , milk 21 , cheese 28 , potatoes 10 , dried legumes 26 , fruits 8 to 13 , vegetables 11 to 35 , bacon 7, meats and fish 15 to 95 , and eggs 32 . Only fats and sugar provide no protein. No common diet could ever contain as little as 6.4 per cent. of protein. But the standards obviously are not to be taken too literally. The analyses of Stiebeling's diets show that, except for energy, the planned diets exceed the standards, sometimes by large amounts (Table 3). For instance, a diet providing 4500 Calories for an adult supplies $112 \mathrm{~g}$. protein.

voL. 1,1944$]$ 
There is a wide range of possibilities in planning diets to meet standards. The N.R.C. did not formulate diets but stated only that their allowances could be obtained from a good diet of natural foodstuffs, which included

TABLE 3

Analysis of Planned Difts per Head of the Population

\begin{tabular}{|c|c|c|c|c|c|}
\hline & & \multicolumn{3}{|c|}{ Stiebeling, $1933^{1}$} & \multirow[b]{2}{*}{$\begin{array}{c}\text { League of } \\
\text { Nations, } \\
1935,1936^{1}\end{array}$} \\
\hline & & $\begin{array}{l}\text { Adequate } \\
\text { diet at } \\
\text { minimum } \\
\text { cost }\end{array}$ & $\begin{array}{c}\text { Adequate } \\
\text { diet at } \\
\text { moderate } \\
\text { cost }\end{array}$ & $\begin{array}{c}\text { Liberal } \\
\text { diet }\end{array}$ & \\
\hline \multicolumn{2}{|c|}{$\begin{array}{c}\text { Energy: Atwater calories in edible } \\
\text { portion } \ldots\end{array}$} & 2980 & 2985 & 2930 & 2980 \\
\hline \multicolumn{2}{|c|}{ Per cent. of total cals. from protein } & 12 & 11 & 12 & 12 \\
\hline Protein & $\begin{array}{llll}\text { g. } & \ldots & \ldots & \ldots\end{array}$ & 89 & 84 & 87 & 89 \\
\hline Carbohydrate & g. .. & 397 & 370 & 310 & 384 \\
\hline Fat & g. $\quad \ldots$ & 115 & 130 & 149 & 121 \\
\hline Calcium & g. $\quad$. & 1.28 & $1 \cdot 26$ & $1 \cdot 27$ & $1 \cdot 30$ \\
\hline Phosphorus & g. $\quad \ldots$ & 1.72 & 1.58 & $1 \cdot 61$ & 1.59 \\
\hline Iron & mg. & 13 & 14 & 15 & 13 \\
\hline Vitamin A & I.Ü. . & 7094 & 7969 & 9093 & $6656^{2}$ \\
\hline Vitamin $B_{1}$ & I.U. . $\quad \ldots$ & $\ldots$ & $\sim$ & - & 580 \\
\hline Vitamin $\mathrm{C}$, asce & orbic acid mg. & $88 \cdot 5$ & 126 & $154 \cdot 5$ & 114 \\
\hline
\end{tabular}

1 Cf. footnote ${ }^{1}$, Table 1.

2 This amount is provided by foods alone. In addition, $3 \mathrm{~g}$. cod liver oil daily are included, giving not less than 1800 I.U. (B.P. standard) and bringing the total to at least $8456 \mathrm{I} . \mathrm{U}$.

"enriched" bread. Stiebeling's diets were planned in great detail, those of the League of Nations only in broad outline. It is easiest to compare these diets if they are expressed as foods required weekly per head of the population (Table 4). When this is done and the resulting average diets analysed in terms of constituents the results are much the same but the proportions of the foods used are different.

When Stiebeling's minimum cost, moderate cost, and liberal, diets are compared, the allowance of cereals, legumes and potatoes decreases, and that of all other foods increases, with cost. The minimum cost diet covers the standards in all the specified nutrients and, as the cost and quality of the diets rise, the excess over the standards prescribed increases, except for energy.

The method to be adopted in the planning of diets to meet standard requirements depends on where the chief emphasis is laid. Formerly diets were planned on the basis of supplying calories or calories and protein within the limits imposed by custom and price, and of accepting other constituents as they might occur. The League of Nations planned first of all the whole or the major part of the protein, minerals and vitamins desired and left the residual requirement, chiefly of energy, to choice. It is obvious that if the foods supplying the major part of the energy in a diet are of such a composition that they supply also the major part of the requirements for the separate food constituents, protein, minerals and vitamins, it will probably be safe to plan for calories in the belief that the rest will take care of itself. But if the staple energy 
supplying foods do not supply the necessary protein, vitamins and minerals in due proportion, then the rest of the diet must be planned to make up the deficit. An examination of the composition of common foods and of the proportions in which they occur in common diets shows that in planning diets attention must be given in the first place to providing calcium and vitamins $\mathrm{A}$ and $\mathrm{C}$ since these do not occur in adequate

TABLE 4

Weerly Food Requirementes per Head of Population: Weights as Purchased

\begin{tabular}{|c|c|c|c|c|c|}
\hline & & \multicolumn{3}{|c|}{ Stieboling, 1933i } & \multirow[b]{2}{*}{$\begin{array}{c}\text { League of } \\
\text { Nations, } \\
1936^{1}\end{array}$} \\
\hline & & $\begin{array}{l}\text { Adequate } \\
\text { diet at } \\
\text { minimum } \\
\text { cost }\end{array}$ & $\begin{array}{c}\text { Adequate } \\
\text { diet at } \\
\text { moderate } \\
\text { cost }\end{array}$ & $\begin{array}{c}\text { Liberal } \\
\text { diet }\end{array}$ & \\
\hline Flour, cereals $\quad \ldots$ & ..oz. & 68.7 & $49 \cdot 1$ & $30 \cdot 7$ & $61 \cdot 6$ \\
\hline Milk, or its equivalent & . pints & $8 \cdot 3$ & $9 \cdot 8$ & $9 \cdot 8$ & $10 \cdot 7^{2}$ \\
\hline Potatocs, sweet potatoes & .oz. & $50 \cdot 6$ & $50 \cdot 6$ & $47 \cdot 6$ & $67 \cdot 8$ \\
\hline Dried beans, peas, nuts & $\ldots$ & $9 \cdot 2$ & $6 \cdot 1$ & $2 \cdot 2$ & $2 \cdot 0$ \\
\hline \multicolumn{6}{|l|}{ Leafy green and yellow } \\
\hline vegetables .. & & $24 \cdot 6$ & $30 \cdot 7$ & $41 \cdot 4$ & $30 \cdot 4$ \\
\hline Dried fruits $\ldots$ & $\ldots$, & $6 \cdot 1$ & $7 \cdot 7$ & $6 \cdot 1$ & - \\
\hline Other vegetables, fruits & $\cdots$ & $26 \cdot 1$ & $64 \cdot 4$ & $99 \cdot 7$ & - \\
\hline \multicolumn{6}{|c|}{ Fats (including butter, oils," } \\
\hline bacon and salt pork) & & $15 \cdot 0$ & $16 \cdot 0$ & $16 \cdot 0$ & $16 \cdot 1$ \\
\hline Sugars $\quad \ldots$ & $\ldots$ & $10 \cdot 7$ & $18 \cdot 4$ & $18 \cdot 4$ & $26 \cdot 0$ \\
\hline Lean meat, poultry, fish & . ., & $18 \cdot 4$ & $30 \cdot 7$ & $50 \cdot 6$ & $25 \cdot 0$ \\
\hline Eggs $\ldots \quad \ldots$ & .. no. & $3 \cdot 5$ & $3 \cdot 5$ & $7 \cdot 0$ & $7 \cdot 0$ \\
\hline
\end{tabular}

${ }^{1}$ Cf. footnote 1 , Table 1.

2 It has been assumed that the liquid millk allowance for persons other than pregnant and lactating women, children and adolescents would be 1 pint per head daily. The liquid milk equivalent of the cheese allowance is included in the total of $10 \cdot 7$ pints.

3 To provide 500 1.U. vitamin C.

amounts in the staple energy supplying foods. In the second place, in certain circumstances only, vitamin $\mathrm{B}_{1}$, iron and protein also should receive special attention since they are present in adequate amounts in the staple foods unless these are highly processed cereals, or include too high a proportion of sugar and pure fats. These deductions are fully supported by the results of dietary surveys everywhere. The constituents most often and most gravely deficient are calcium and vitamins $A$ and $\mathrm{C}$. Unfortunately the amounts of sugar and of processed cereals used are so high in many areas, especially in the diets of the poor, that deficiency of vitamin $B_{1}$ also, in extreme or minor degrees, is thought to be common.

If the average diet of the United Kingdom were to be modified to the pattern of Stiebeling's moderate cost or liberal diet the most important increases (Table 5) would be in consumption of liquid milk which would be doubled, of eggs which might also be doubled, of fruit which would be doubled or trebled, and of vegetables, other than potatoes, which would VoI. 1, 1944] 


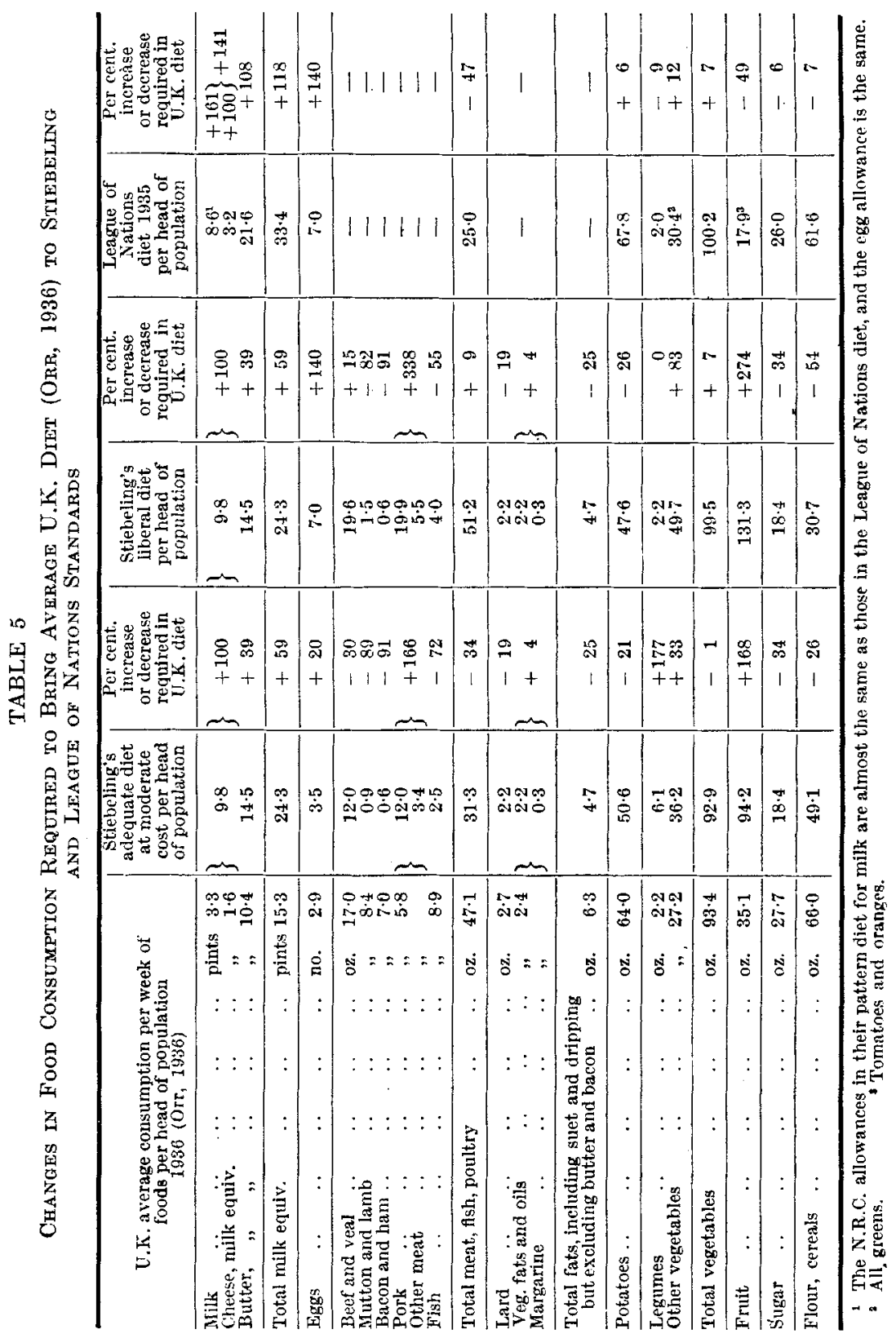


have to be substantially increased. Consumption of meat and fish together would be maintained or reduced, and cereals and potatoes reduced. This American pattern of food consumption would not, in all respects, suit either our habits or our agriculture, as for instance, in the replacement of mutton by pork, nor would there be any advantage from such a replacement, or from reducing fish consumption here where fish is easy to obtain in peace time. These issues are relatively unimportant. The nature of the main increases required is clear. It will be the task of the later speakers to discuss whether and how these changes may be brought about.

Plans to provide food for health are required even more urgently in other parts of the world than here or in the United States, and the question immediately arises whether plans of the same type are to be aimed at everywhere with adjustments to suit different areas. The magnitude of the world problem is illustrated by a recent survey (Bennett, 1941) of the position of cereals and potatoes in human diets (Table 6).

TABLE 6

The Positron of Cereals and Potatoes in Humax Diets (BENNETT, 1941)

\begin{tabular}{|c|c|c|}
\hline $\begin{array}{l}\text { Per cent. of } \\
\text { calories from } \\
\text { cereals and } \\
\text { potatoes } \\
\text { (including } \\
\text { cassava) }\end{array}$ & Countries & $\begin{array}{l}\text { Total } \\
\text { population } \\
\text { millions }\end{array}$ \\
\hline $\begin{array}{l}30 \text { to } 40 \\
40 \text { to } 50 \\
50 \text { to } 60 \\
60 \text { to } 70 \\
70 \text { to } 80 \\
80 \text { to } 90\end{array}$ & 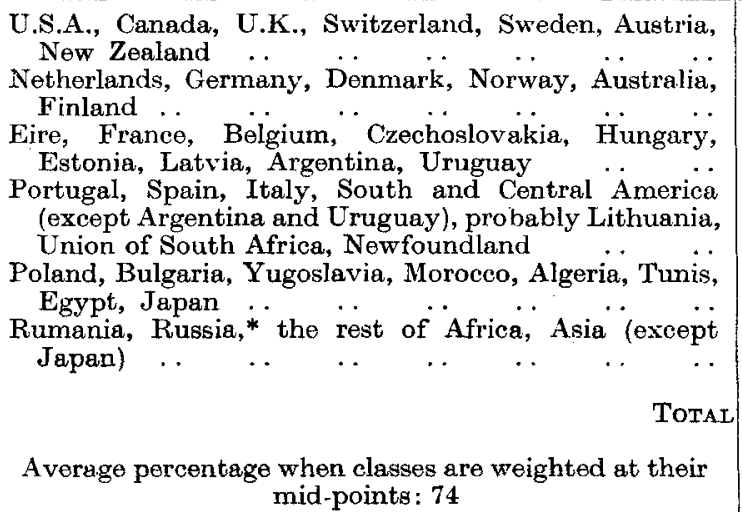 & $\begin{array}{c}204 \\
156 \\
\frac{1344^{*}}{2095}\end{array}$ \\
\hline
\end{tabular}

* Bennett includes Russia in this class on the basis of statistics for 1928. These are probably not applicable now but information is not available to show where Russia should be placed on the scale.

Within each country, it is pointed out, there is an economic gradient, the percentage of calories derived from cereals and potatoes increasing with decrease in purchasing power. It may be added that, in general, as consumption of cereals and potatoes together increase, that of potatoes decreases relatively to cereals. The proportion of energy derived from each is of the following order: in the class in which 30 to 40 per cent. of roI. J, 1944] 
the energy is derived from cereals and potatoes, 5 parts are from cereals and I part from potatoes; in the class where 70 to 80 per cent. of the energy is from the same two sources, 55 parts are from cereals and 1 from potatoes. This rule breaks down in areas where a substantial part of the energy of the diet is derived from cassava, grouped, since it is a root, with potatoes; that is, for instance, in parts of Africa and the Netherlands East Indies.

Obviously modification of the pattern of all these diets to that at which we are aiming would not only present a colossal task but also change the whole position of world trade in food and feeding stuffs. Great changes in cropping policy and a great extension of animal husbandry would be necessary throughout the world, and the future plans of importing countries like ours must to some extent depend on the extent and the rate of change in other parts of the world.

The question of provisioning adequately the entire world population of 2000 million people involves two immediate questions in addition to the main problem of increasing, as rapidly as may be, the total supply of protective foods. The first of these problems is that of qualitative deficiencies in staple foods. The replacement of cassava requires research on drought resistant cereals and legumes which could be introduced into the infertile areas where cassava is now used. The problem of overmilled cereals affects a large part of the world. It might be tackled directly by voluntary cessation or prohibition of overmilling, or indirectly by enrichment of the milled product, or possibly by selection and breeding of wheats of high vitamin content in the hope that a white bread, containing an adequate supply of vitamin $B_{1}$, might be produced. The last would be a long term policy in any case, and one of the first two possibilities must be considered, on a temporary or permanent basis.

The second problem in provisioning the whole world is that of food preservation and distribution. Present methods of storage and preservation are inefficient. Marketing, especially of fresh fruit and vegetables, is haphazard and wasteful. The loss of some crops between harvesting and the table is possibly as high as 50 per cent. Measures to deal with these problems could be taken now, and would effect a considerable gain during the interval while plans for organizing food production are being made and put into operation. Further, the general level of productivity of the soil lags far behind the yields which research into soil and crop management, plant and animal breeding, animal husbandry and the control of pests and disease has made possible. If science were consistently applied to increase production and avoid waste, there would be no insuperable obstacle to the planned provision of adequate food for all men in all lands.

\section{REFERENCES}

Bennett, M. K. (1941). Geogr. Rev. 31, 365.

League of Nations Health Organization (1937). Bull. Hlth Org. L.o.N. 6, 129 ; $137 ; 141$.

Orr, J. B. (1936). Food, Health and Income. London: Macmillan.

Orr, J. B. (1944). Proc. Nutr. Soc. 1, 43.

Stiebeling, H. K. (1939). Yearb. U.S. Dep. Agric. p. 380. 


\section{The Potential Contribution of Milk, Meat and Eggs to the British Diet}

\section{Dr. N. C. Wright (Hannah Dairy Research Institute, Kirkhill, Ayr)}

In the preceding paper Dr. Leitch provided a broad survey of the problem of relating food production and imports to the nutritional needs of the population (Leitch, 1944). The present paper deals in detail with one special aspect of the problem, namely, the supply of animal products. The clearest way in which the subject can be presented is to attempt to answer four general questions. First, are the general standards for the three main classes of products, milk, meat and eggs, satisfactory? Second, how far are Stiebeling's allocations within each of the three groups applicable to British conditions? Third, to what extent should we be justified in relying on imports to meet the country's increased nutritional needs? Fourth, what modifications in home production, and concurrently in home cropping policy, would be entailed if the new standards were adopted? The two last questions are, of course, very closely interrelated since imports and home production are complementary.

First, then, are the general standards discussed by Dr. Leitch satisfactory as a basis for allotting the supply of animal products? While it would be outside the scope of this paper to criticize the validity of these standards from the point of view of nutritional needs, they do need qualification in two directions. In the first place it is doubtful whether butter can justifiably be included under the same heading as milk and cheese, and it is certainly misleading to convert butter into terms of "milk equivalent." We consume milk and milk products primarily, as Stiebeling herself states, as sources of first class protein and mineral salts, and only secondarily as sources of fat and fat soluble vitamins. In making butter practically the whole of the protein and mineral salts is eliminated, and these constituents reappear in the diet only if they are consumed in the form of condensed or skimmed milk. Actually we import into this country a quantity of butter equivalent to 2500 million gallons of milk, but we only import skimmed milk products corresponding to about 2 per cent. of this amount. The remaining 98 per cent. of the skimmed milk is retained in the country of origin, where it is mostly used for stock feeding. In these circumstances it would clearly be misleading to imply in a dietary analysis that we had consumed the full milk equivalent of our imports of butter. Moreover, improved methods of margarine manufacture and, in particular the vitaminization of margarine, have provided a butter substitute which can be readily obtained from vegetable or whale oils, a fact which greatly reduces the need for such a high butter consumption. In this paper butter will therefore be excluded from the statistics of dairy products.

Further, it will be easier in dealing with statistics of production to readjust Stiebeling's sub-classifications of the meat group. No complete information is available of the quantity of bacon and ham produced in this country, and it will, therefore, be more accurate to reclassify bacon, ham and pork into the single category of pigmeat. For simplicity, "other meat," which chiefly comprises poultry, has been omitted from

vor. 1,1944 ] 
consideration, since in the British diet it constitutes such a small fraction of the total meat consumption, not more than 4 per cent. Finally fish has been omitted from consideration, since this is being dealt with in a separate paper by Dr. Lovern (Lovern, 1944). The summarized figures, modified on the above basis, are shown at the head of Table 1.

\section{TABLE 1}

Average Wegkly Consumptron per Head of the Population of Amimal Products in Various Countries ${ }^{1}$ Compared with the Standards of Stiebeling and of The League of Nations

\begin{tabular}{|c|c|c|c|c|c|c|c|c|}
\hline & $\begin{array}{l}\text { Total } \\
\text { meat } \\
\text { (oz.) }\end{array}$ & $\begin{array}{l}\text { Beef } \\
\text { and } \\
\text { yeal } \\
\text { (oz.) }\end{array}$ & $\begin{array}{c}\text { Mutton } \\
\text { and } \\
\text { lamb } \\
\text { (oz.) }\end{array}$ & $\begin{array}{l}\text { Pig. } \\
\text { meat } \\
\text { (oz.) }\end{array}$ & $\begin{array}{l}\text { Eggs } \\
\text { (no.) }\end{array}$ & $\begin{array}{l}\text { Milk } \\
\text { (pt.) }\end{array}$ & $\begin{array}{l}\text { Cheese } \\
\text { (oz.) }\end{array}$ & $\begin{array}{c}\text { Butter } \\
\text { (oz.) }\end{array}$ \\
\hline $\begin{array}{l}\text { STANDARDS : } \\
\text { Stiebeling }\end{array}$ & & & & & & & & \\
\hline Adequate & 28 & 12 & 1 & 15 & $3 \frac{1}{2}$ & 7 & $5 \frac{13}{2}$ & $12 \frac{1}{2}$ \\
\hline Liberal & $44 \frac{1}{2}$ & 20 & $1 \frac{1}{2}$ & 23 & 7 & 7 & $5 \frac{1}{2}{ }^{3}$ & $12 \frac{2}{2}$ \\
\hline $\begin{array}{r}\text { League of Nations } \\
1935\end{array}$ & $23^{4}$ & $?$ & $?$ & ? & 7 & $8 \frac{1}{2}$ & $6 \frac{1}{2}$ & 18 \\
\hline $\begin{array}{l}\text { CONST MPTTON : } \\
\text { United Kingdom }\end{array}$ & & & & & & & & \\
\hline Home produced & $19 \cdot 1$ & $9 \cdot 2$ & $3 \cdot 4$ & $6 \cdot 5$ & 1.8 & $3 \cdot 1^{5}$ & $0 \cdot 6$ & 0.6 \\
\hline Imported & $22 \cdot 0$ & $10 \cdot 1$ & $5 \cdot 3$ & $6 \cdot 6$ & $1 \cdot 6^{6}$ & $0 \cdot 2^{s}$ & $2 \cdot 1$ & $6 \cdot 9$ \\
\hline 'Total & $41 \cdot 1$ & $19 \cdot 3$ & $8 \cdot 7$ & $13 \cdot 1$ & $3 \cdot 4$ & $3 \cdot 3$ & $2 \cdot 7$ & $7 \cdot 5$ \\
\hline Australia & 61 & 41 & 23 & 5 & ? & $3 \frac{1}{2}$ & $1 \frac{1}{2}$ & 11 \\
\hline New Zealand & 70 & 46 & 31 & 8 & ? & $4 \frac{1}{2}$ & $2 \frac{1}{2}$ & 12 \\
\hline Canada $\quad \ldots$ & 44 & 19 & 2 & 21 & 5 & $?$ & 1 & 10 \\
\hline United States & 42 & 23 & 2 & 21 & $4 \frac{1}{2}$ & 6 & $1 \frac{1}{2}$ & 5 \\
\hline Germany .. & 34 & 11 & $\frac{1}{2}$ & 23 & $2 \frac{1}{2}$ & $3 \frac{1}{2}$ & $3 \frac{1}{2}$ & 6 \\
\hline France & 26 & 14 & $2^{2}$ & 11 & 3 & $3 \frac{1}{2}$ & 4 & 4 \\
\hline Argentina .. & 75 & 68 & 4 & 11 & $?$ & $?$ & $1 \frac{1}{2}$ & $1+$ \\
\hline
\end{tabular}

1 Figures calculated to nearest round number from Imperial Economic Committee's Reports on Meat and Dairy Produce, 1937-38. London: H.M.S.O.

2 Excluding poultry.

${ }^{3}$ Calculated as same milk/cheese ratio as for League of Nations, 1935 standards.

- Includes fish.

5 Includes condensed and dried milks.

${ }^{6} 1.2$ in shell and 0.4 imported as liquid eggs.

The second general question may now be considered. How far are Stiebeling's allocations within each group of foods applicable to British conditions? As regards dairy products her standards are based on a figure for total milk consumption covering liquid milk, condensed and dried milks, and cheese, but excluding butter. It will be seen from Table 1 that the American consumption of cheese is exceptionally low, and this may account for her hesitation in allocating any definite proportion of the milk to cheese. If, however, the League of Nations dietary ratio was applied to Stiebeling's figures, the milk allowance would work out at 1 pint per head per day for consumption in liquid or cooked form, together with a little over $5 \mathrm{oz}$. of cheese per head per week. This is nearly twice the pre-war British figure and nearly four times the American. In fact it is only approached in Switzerland and Holland, 
which are two of the most active cheese producing countries. It is difficult to explain this general low level of cheese consumption. It seems possible that it is due to the very pronounced flavour of cheese, for it is usually true that those foods which are most widely acceptable, e.g. cereals and potatoes, meat and fruits, derive their popularity from the neutrality or the delicacy of their flavours. The low level of cheese consumption is the more remarkable because the pre-war price of cheese made it, in comparison with meat, a most economical source of protein and energy; that the phenomenon is not due to economic factors is shown, too, from the fact that the consumption per head does not rise above $3 \frac{1}{2}$ oz. even among the highest income groups of the population (Orr, 1936). This point has been dealt with in some detail because it is clearly relevant to the general question of the desirable level of milk production. Most housewives would probably have difficulty in disposing of more than 1 pint per head per day of liquid or preserved milk; if Stiebeling's figure of 10 pints per week is to be adopted as a standard, an increase in cheese consumption would appear to be the only means of securing consumption of the additional 3 pints.

The sub-division of meat between beef, mutton and pigmeat involves a more complex problem. Stiebeling and Ward (1933) states that her figures are based "on the relative consumption of the several articles of food in the United States, and that they do not represent the selection which would give the highest nutritive content of the diets." From this point of view the relatively high proportion of pigmeat consumed in Canada and the United States, and the equally high proportion of mutton consumed in Australia and New Zealand, and of beef in Argentina, all of which are shown in Table 1, might be attributed simply to dietary habit. In considering production problems it is, however, necessary to be clear as to the underlying causes of such marked differences in dietary habit as those which have been instanced. Briefly, there are four main underlying causes. The first is the effect of climate and soil on the nature of the local agricultural output. Thus the pastoral character of Australia, and particularly of New Zealand, the largest mutton exporting country in the world, favours the growth and fattening of sheep and cattle, while the cereal belt of North America provides suitable crops and crop by-products for the intensive production of pigmeat. Such ecological factors do not merely affect the proportion of each animal product consumed, they also determine the absolute level of consumption, as will be seen from the extraordinarily high beef consumption of Argentina and the almost equally high total meat consumption of Australia and New Zealand.

The second underlying cause of the observed differences in dietary habit is the effect of political factors. This is most clearly illustrated in the figures for the meat consumption of the United Kingdom. British needs in times of peace must be harmonized with Britain's imperial and financial interests and obligations. Thus it will be seen from Table 2 that Australia and New Zealand look to Britain as a market for their enormous surpluses of mutton, while Argentina repays the interest on our South American holdings by a vast export trade in beef. Canada, too, is building up an increasing overseas trade in pigmeat, while Danish bacon is the necessary corollary to our imports of Danish butter.

vor. 1, 1944] 
The third underlying cause of differing dietary habits is the price factor. This is, of course, a well recognized reason for differences in food consumption between population groups living at different income levels; it is, however, equally potent in determining, through the medium of international exchange rates, the origin and therefore the nature of food imports.

TABLE 2

Areas of Origin of Imported Animal Products and Animal Feedingstuffe*

\begin{tabular}{|c|c|c|c|c|c|c|c|c|c|c|}
\hline \multirow[b]{2}{*}{ Commodity } & \multicolumn{10}{|c|}{ Percentage of total imports drawn from } \\
\hline & $\begin{array}{c}\text { North } \\
\text { America }\end{array}$ & $\begin{array}{c}\text { South } \\
\text { America }\end{array}$ & Africa & $\begin{array}{c}\text { India } \\
\text { and } \\
\text { Malaya }\end{array}$ & $\begin{array}{c}\text { Australia } \\
\text { and } \\
\text { New } \\
\text { Zealand }\end{array}$ & $\begin{array}{c}\text { Baltic } \\
\text { and } \\
\text { Low } \\
\text { Countries }\end{array}$ & $\begin{array}{c}\text { Eastern } \\
\text { Mediter- } \\
\text { ranean }\end{array}$ & $\begin{array}{c}\text { Other } \\
\text { countries } \\
\text { includ- } \\
\text { ing Eire) }\end{array}$ & $\begin{array}{c}\text { Empire } \\
\text { countries }\end{array}$ & $\begin{array}{l}\text { Foreign } \\
\text { countries }\end{array}$ \\
\hline $\begin{array}{l}\text { Aniwral } \\
\text { Products: } \\
\text { Beef and veal }\end{array}$ & 0.7 & $i 2 \cdot 3$ & $0 \cdot 1$ & - & $26 \cdot 1$ & 0.5 & - & $0 \cdot 3$ & $27 \cdot 5$ & $72 \cdot 5$ \\
\hline $\begin{array}{l}\text { Mutton and } \\
\text { lamb }\end{array}$ & 0.8 & $19 \cdot 6$ & 一 & $\ldots$ & & & & 0.2 & & \\
\hline Pigmeat $\quad$. & 19.3 & $7 \cdot 3$ & - & $=$ & 9.7 & $55 \cdot 8$ & $\overline{0 \cdot 4}$ & $7 \cdot 5$ & $\begin{array}{l}80 \\
33 \\
\end{array}$ & $\begin{array}{l}20 \cdot 0 \\
66 \cdot 7\end{array}$ \\
\hline Butter & 0.3 & 1.0 & $0 \cdot 7$ & - & $46 \cdot 2$ & 47.9 & 0.2 & $3 \cdot 7$ & 50 & $49 \cdot 5$ \\
\hline $\begin{array}{l}\text { Cheese } \\
\text { Eggs in sheli }\end{array}$ & $23 \cdot 2$ & & $0 \cdot 8$ & - & $64 \cdot 1$ & $8 \cdot 2$ & $2 \cdot 4$ & $1 \cdot 3$ & 88.5 & $11 \cdot 5$ \\
\hline $\begin{array}{l}\text { Eggs in shell } \\
\text { Eggs, all }\end{array}$ & 0.6 & $3 \cdot 6$ & 0.9 & - & & $72 \cdot 0$ & 8.7 & $10 \cdot 5$ & $13 \cdot 5$ & $86 \cdot 5$ \\
\hline $\begin{array}{l}\text { forms } \\
\text { Feedingstuffs: }\end{array}$ & $0 \cdot 6$ & $2 \cdot 7$ & 0.7 & - & $2 \cdot 9$ & $54 \cdot 6$ & $8 \cdot 8$ & $29 \cdot 7$ & $10 \cdot 2$ & $89 \cdot 8$ \\
\hline $\begin{array}{l}\text { Cereal } \\
\text { products . }\end{array}$ & $19 \cdot 4$ & 47.8 & $2 \cdot 8$ & $5 \cdot 1$ & $6 \cdot 2$ & $8 \cdot 8$ & $7 \cdot 8$ & $2 \cdot 1$ & $27 \cdot 5$ & $72 \cdot 5$ \\
\hline $\begin{array}{l}\text { Oilseed } \\
\text { products .. }\end{array}$ & $1 \cdot 8$ & $10 \cdot 1$ & 18.0 & $39 \cdot 4$ & $0 \cdot 3$ & $2 \cdot 4$ & $25 \cdot 8$ & $2 \cdot 2$ & $53 \cdot 5$ & $46 \cdot 5$ \\
\hline
\end{tabular}

* Figures calculated from Annual Statement of the Trade of the United Kingdom, Vol. 2, 1938. London: H.M.S.O.

The fourth underlying cause of differing dietary habits is the effect of climatic and other environmental factors on the actual food requirement of man himself. The importance of this factor has not yet been determined, nor has its exact influence on dietary habit been assessed. Moreover, while there is little doubt that it does affect the nutritional status of widely separated populations such as those of the temperate and tropical zones, it is hardly germane to the present discussion. The first three underlying causes are, however, clearly relevant, and support the view that in adopting Stiebeling's general standards for meat, this country's present allocation as between beef, mutton and pigmeat should not be unduly or unnecessarily disturbed. No discussion is necessary regarding the egg allowance, which is a straightforward figure.

The following statement therefore summarizes the final standards to be aimed at, as modified by the foregoing discussion. Milk consumption would have to be roughly doubled, and a similar increase would be desirable in cheese consumption. The total meat consumption might be reduced by 25 per cent. to, say, 30 oz., the mean value between the League of Nations standard and Stiebeling's liberal allowance. The subdivision of meat between beef, mutton and pigmeat should, however, follow British rather than American food habits, which would place the dietary requirements at roughly $14 \mathrm{oz}$. of beef, $7 \mathrm{oz}$. of mutton and $9 \mathrm{oz}$. of pigmeat per head per week. It may be noted that of this last amount, existing food habits indicate that two-thirds should be available as bacon and ham, and one-third as pork. Finally, egg consumption should if possible be doubled, the new standard providing for something of the order of one egg per head per day. 
So far we have dealt with national food requirements. Let us turn now to the third general question which was propounded at the beginning of this paper. To what extent should we attempt to modify food imports to meet these revised dietary standards? It will be convenient to deal first with meat, since with this commodity we are looking for some means of reducing rather than of increasing supplies.

The beef requirement has been placed at $14 \mathrm{oz}$. per head per week. Reference to the figures for imported produce in Table 1 shows that beef imports already provide $10 \mathrm{oz}$. per head. If imports were to be retained at this figure, the adoption of the new standards would involve a reduction in the home output by nearly 60 per cent., from $9 \cdot 2$ to only $4 \mathrm{oz}$, per head. Similarly with mutton the retention of imports at their pre-war level would necessitate a reduction of home production to less than half. Such a drastic curtailment in the home output of beef and mutton could not possibly be envisaged, more especially as our pastures and crop rotations are specially suitable for fattening these classes of stock. It would appear that the fairest way would be to plan for the same proportionate reduction in both imports and home output, that is, to plan for an all round reduction in output of 25 per cent. As regards exportation of beef, Argentina would be the country chiefly affected, since that country provides nearly three quarters of our total imports (see Table 2). At present Argentina and her South American neighbours rely on the United Kingdom to absorb almost the whole of their exportable surpluses of beef. There seems no reason why, under a more rational economic system, any reduction in the exports to the United Kingdom should not be made good by diverting the released surplus to less favourably situated countries, notably the Central European States and the Far East.

The bulk of our supplies of mutton are drawn from New Zealand and Australia, which together provide nearly 80 per cent. of our total imports. Reference to Table 1 shows, however, that there should be no difficulty in disposing of any of the released surplus which would result from our decreased demand; without exception, every country shows only a fraction of the consumption per head found in Britain and, under a rational economic system, should be capable of absorbing far larger quantities than are used at present.

Pigmeat presents a rather different problem. For reasons which will be detailed later, it is unlikely that home production will again reach the pre-war level, and a reduction in imports to coincide with the revised standards will not therefore be so necessary. Indeed, the virtual extinction of the Danish bacon industry as a result of the present German occupation, and the possible re-orientation of the Danish dairy industry to produce milk products more valuable than butter, may well involve at least a temporary shortage in the quantities of pigmeat available for importation into this country. This might, however, quite possibly be counterbalanced by increased imports from the United States, for it is significant to note that in the last war American consignments of bacon far more than replaced Danish supplies, increasing from about 130,000 tons in 1913 to over 500,000 tons in the peak year of 1918. It is apparent, in any event, that the future pigmeat position need not worry us unduly, whether we have to budget for a rise or a fall in the level of imports.

voL. 1,1944$]$ 
If we now turn to dairy products and eggs, the problem is the reverse of that presented by meat. The new standards indicate that the consumption, and therefore if possible the imports, of milk, cheese and eggs must all be markedly increased. Reference to Table 1 shows, however, that the ratio of imported to home produced supplies varies for each commodity, so that each will require separate treatment. Thus for eggs, the home and overseas producers share the market more or less equally; for cheese, we rely on imports for nearly 80 per cent. of our supplies, while for milk the home producer virtually holds the monopoly.

Of imported eggs, it will be seen from Table 2 that three-quarters of those supplied in shell are derived from the Baltic and Low Countries, Denmark, Holland, Belgium and Poland. German occupation is likely to have seriously disorganized the poultry industries of these countries and, although poultry populations can be built up very quickly because of their rapid rate of reproduction, it is unlikely that any large exportable surplus will be available from the Continent for a very considerable period. It will be seen, however, that if eggs in all forms are considered, there is a marked increase in the proportion derived from "other countries." This is due to the inclusion of liquid eggs from China, the imports of which are equivalent to over 1000 million eggs in shell, or over a quarter of our total overseas supplies. The need of new markets for our industrial products after the war may well lead us to look to China as a potential outlet for our manufactured goods, and if so, we should be prepared to increase very substantially our imports of Chinese eggs. If, as seems probable from current developments in food dehydration, such eggs can be consigned in dry rather than liquid form, they will certainly command an increasingly wide market in this country and their transport will, in addition, present a less difficult problem than hitherto.

The great bulk of British imports of cheese has in the past been derived from our overseas Dominions, notably from New Zealand and Canada. Denmark's contribution has been negligible, while imports from Holland and Italy have been confined to fancy types. As regards condensed milk, which is the only form in which imports have in the past substantially supplemented home produced liquid milk, Holland has enjoyed a virtual monopoly, consigning to this country over ten times the quantity supplied by any other single state. Unless a very marked increase can be effected in the production of milk in our overseas Dominions, or unless milk used for other purposes can be diverted to these products, it is difficult to see how their importation can be substantially. increased. One form of diversion does, however, appear to be eminently feasible, namely, the diversion of milk from butter making to cheese making.

The possible substitution of margarine for butter has already been mentioned, and it bas been pointed out that it constitutes an economical and rational means of providing a suitably vitaminized and palatable form of fat. Before the war the consumption of margarine was already showing a steady and, from the point of view of the butter producing countries, an alarming increase. Improvements in the methods of margarine manufacture, the extensive use of margarine by all classes of the community under war conditions, and the decline in the quality of butter through the pooling of war supplies, will all tend to enhance the popularity of margarine in post-war years. If in fact margarine does 
tend to replace butter in the average family diet, considerable quantities of overseas milk will be released for other purposes such as the manufacture of cheese and the production of condensed and dried milks. Thus if only one-third of the milk used for butter production in New Zealand and Australia were to be diverted to cheese making, enough cheese could be produced to increase our weekly allowance of $3 \mathrm{oz}$. to the required figure of $5 \frac{1}{2} \mathrm{oz}$. while, if half the milk were diverted from butter making for the joint purposes of cheese making and the production of condensed and dried milks, the liquid milk supply could, in addition, be supplemented by the equivalent of nearly 200 million gallons, or nearly a quarter of this country's liquid milk consumption. These figures illustrate the enormous supply of milk products which could be made available by their diversion from butter manufacture at no loss, but rather at a gain, in available nutrients. In actual practice such a diversion could be spread over other exporting countries, and might with particular advantage be applied to Denmark, where the skimmed milk from butter making has in the past been used for bacon production, an uneconomical method of utilization. There would still be available for the bacon industry very considerable quantities of whey, which would form a reasonably satisfactory substitute for skimmed milk in pig feeding.

Let us turn now to the fourth and final question propounded at the beginning of this paper. What modifications in home production, and concurrently in home cropping policy, would be necessary if the new standards were adopted? It is clear from Table 1 that the first aim must be to increase liquid milk production. Even if we can import substantial quantities of condensed and dried milks, it will still be necessary to raise our home supplies of liquid milk by from 50 to 100 per cent. How can this be done?

It has already been shown that the adoption of the new standards will necessitate some reduction in the home output of meat, and it has been tentatively suggested that the reduction to be aimed at should be 25 per cent. How far could the resulting release of productive capacity be harnessed to the increasing of milk production? Superficially the problem might appear to be an easy one. Beef and dairy cattle subsist on essentially the same types of nutrients, although the latter require a rather higher level of protein in their rations. The relative efficiencies of conversion of feedingstuffs into milk and meat are well recognized, the efficiency of milk production being at least twice that of meat produotion. There are, however, several practical diffoulties. In the first place milk production itself involves meat production on a considerable scale; nearly one-third of the present beef output is cow beef. In the second place, beef cattle are reared in many areas not so much for meat production as for the production of farmyard manure, an essential step in maintaining the fertility of our arable areas. In the third place a substantial turnover from meat to milk would interfere seriously with established agricultural practice in many localities, while the natural caution and conservatism of the farmer is, for very good reasons, never easy to overcome. Moreover, even if these and other difficulties could be met, and the whole of the planned reduction in beef output could be achieved, the resulting increase in milk output would only amount to some 12 per cent. or about one-eighth of the necessary figure.

VOL. 1,1944$]$ 
There is, however, another and even more serious difficulty with which the country is likely to be faced in striving for increased milk production. It will be seen from Table 3 that in pre-war years cereals and protein

TABLE 3

Feedingstuffs Required for the Livestock of the United Kingdom, Average for 1934-8, Expressed in Thousands of Tons of Starch Equivalents*

\begin{tabular}{|c|c|c|c|c|}
\hline \multirow[b]{2}{*}{ Class of livestock } & \multirow[b]{2}{*}{$\begin{array}{c}\text { Total re- } \\
\text { quirements }\end{array}$} & \multicolumn{3}{|c|}{ Proportions derived from } \\
\hline & & $\begin{array}{l}\text { Cereals and } \\
\text { concentrates }\end{array}$ & $\begin{array}{l}\text { Roots and } \\
\text { straw }\end{array}$ & $\begin{array}{l}\text { Grass and } \\
\text { hay }\end{array}$ \\
\hline Dairy cattle $\quad$. & 5580 & 1060 & $\begin{array}{c}780 \\
\text { (14) }\end{array}$ & 3740 \\
\hline Beef cattle and sheep & 11,710 & 2030 & 2660 & 7020 \\
\hline Pigs $\quad$. & 2000 & 1940 & - Pot & $\begin{array}{c}60 \\
(3 \text { per cent.) }\end{array}$ \\
\hline Poultry & 1652 & 1552 & - & $\begin{array}{c}100 \\
0\end{array}$ \\
\hline Horses .. & 2260 & $\begin{array}{c}\text { (94 per cent.) } \\
560 \\
\text { (25 per cent.) }\end{array}$ & & $\begin{array}{c}\text { (6 per cent.) } \\
1700 \\
\text { (75 per cent.) }\end{array}$ \\
\hline Total, all stock & 23,202 & $\begin{array}{c}7142 \\
\text { (31 per cent.) }\end{array}$ & $\begin{array}{c}3440 \\
\text { (15 per cent.) }\end{array}$ & $\begin{array}{c}12,620 \\
\text { (54 per cent.) }\end{array}$ \\
\hline
\end{tabular}

* Figures from Wright (1940).

rich concentrates constituted nearly 20 per cent. of the rations of dairy cattle. As far as milk production itself is concerned this figure is an underestimate, for a considerable part of the grass and hay allocated to dairy cattle would in fact be consumed by young stock. The million odd tons of starch equivalent available as cereals and concentrates would, if used for milk production alone, have been capable of producing nearly a thousand million gallons of milk, or two-thirds of the country's total output. It is probable that in practice only about half the cereals and concentrates are actually used for milk production, the remainder being given to young stock and heifers and cows in calf. Even so, the contribution of cereals and concentrates to milk production is very substantial, and is of particular significance in considering the supply of winter milk.

The difficulty with which we may be faced in post-war years is that a very large proportion of the cereals, and practically the whole of the protein rich concentrates, are normally derived from overseas. Moreover, imports of the latter are likely to constitute a special problem, since they are, as shown in Table 2, almost entirely derived from tropical countries whose own milk consumption is already far less adequate than ours. For instance, even if the whole of the by-products of the Indian oilseed industry were to be retained in India and used for Indian milk production, the level of Indian milk consumption would still be less than half that recommended in Stiebeling's standards. The same general argument holds for Egypt, the source of much of the world's cottonseed, and for our African dependencies such as Nigeria and Kenya, which produce almost the whole of the balance of the world's output of oilseerls 
and nuts. If, therefore, we are to strive in post-war years for a higher standard of living in all countries of the world, and particularly in those tropical areas where the level of nutrition is already very inadequate, we cannot hope to import the same quantities of oilseed products, or even of feeding cereals, as we did in pre-war years. We shall therefore be thrown to a very much greater extent on home production for our supplies of feedingstuffs.

In this connexion the war is providing both a testing ground and a training ground, since we are at present faced with a similar urgent need for increased self-sufficiency as a result of the severe curtailments in the supplies of imported feedingstuffs. The lines along which a solution is being attempted may be briefly. summarized as follows: First, there has been a substantial turnover from grass to arable cultivation, a procedure which is intended, among other things, to provide increased supplies of cereals, roots and other fodder crops suitable for winter stock feeding. Second, an effort has been made to secure a substantial increase in the productivity of the remaining grassland. The ploughing up campaign will itself assist in this direction by replacing old worn out pastures with improved grass mixtures, while other developments, notably the more extensive use of nitrogenous fertilizers accompanied by adequate liming, are capable of effecting very material gains in the yield of herbage. Side by side with this, any improvement in the poorer pastures, at present suitable only for sheep grazing, would enable the grazing area for young growing cattle to be considerably extended. Third, there has been an attempt to develop new and improved means of conserving summer crops, and particularly surplus summer grass, for use during the winter months when milk production is largely dependent on an adequate supply of protein rich feeds. Fourth, there has been a gradual turnover towards summer milk production. An essential accompaniment to this trend would be a substantial increase in the country's facilities for condensing and drying the surplus summer milk. Here again our war time experience is accustoming the population to use preserved milks in place of fresh milk, while research into better means of preservation and storage is likely to improve both the palatability and nutritive value of the resultant products.

Milk production has been dealt with at some length because it is of such outstanding importance in planned nutrition. Whether a return of the pig population to the pre-war figure will be possible, even if it is desirable, will depend very largely on the possibility of securing post-war imports of cereals. The same consideration holds as regards poultry, though it will be seen from Table 1 that a substantial expansion in the output of eggs is clearly warranted. Possibly the present tendency towards increased egg production on small farms and by individual households may help to provide part of the desired increase, though the contribution so made is unlikely to meet either the country's requirements or the housewife's demand.

\section{REFERENCES}

Leitch, I. (1944). Proc. Nutr. Soc. 1, 60.

Lovern, J. A. (1944), Proc, Nutr. Soc, 1, 76.

Orr, J. B. (1936). Food, Health and Income. London: Macmillan.

Stiebeling, H. K. and Ward, M. M. (1933). Circ. U.S. Dep. Agric. no. 296.

Wright, N. C. (1940). Empire J. exp. Agric. 8, 248.

จoL. 1, 1944] 


\title{
The Potential Contribution of Fish to the British Diet
}

\author{
Dr. J. A. Lovern (Torry Research Station, Aberdeen)
}

The figures presented in this paper relate to the landings of fish in 1938, and it is believed that they give a sufficiently accurate idea of what the industry is likely to contribute after the war. The question of possible expansion or diminution of supplies is discussed later.

In Table 1 are shown the total landings of demersal fish from British fishing vessels, at ports in England, Scotland and Wales. The more important species are given separately.

\section{TABLE I}

Total Landings of Demersal Fish for 1938

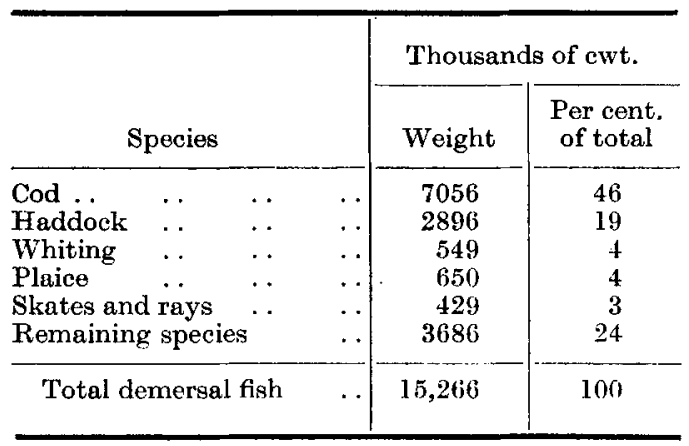

Imports and exports of demersal fish, that is bottom dwelling forms commonly called white fish, are small in comparison with the total landings. In addition, the imports and exports roughly balance each other, and it is safe to take the figures in Table 1 as an indication of the total contribution of British caught demersal fish to the British diet in 1938.

These figures represent landed weights of whole fish without the viscera. In whatever way the fish are handled the portion finally consumed as food is such flesh as can readily be separated from the bones. This edible portion corresponds quite closely with the commercial fillet. From reference to various authorities (Chatfield and Adams, 1940; Monssen, 1930; Torry Research Station, 3) it seems clear that for cod and haddock the fillet averages about 40 per cent. of the weight of the landed fish, and the same ratio is applicable to most white fish. Thus, the total weight of edible material available from demersal fish, as based on the 1938 landings, is about $6,105,000 \mathrm{cwt}$. If all the fish were filleted at the ports, the whole of the balance of $9,161,000 \mathrm{cwt}$. would be available for the manufacture of fish meal. In actual practice the fish meal manufacturers in Aberdeen reckon to obtain about one-third of the landed weight. If this can be taken as a guide for the rest of the country, there is, with present methods of handling and distribution, a potential supply of about 5,000,000 cwt. of raw material for the manufacture of fish meal, or, say, an actual meal production of about 1,000,000 cwt. $(50,000$ tons). This fish meal represents an indirect contribution to our 
diet, through the medium of the farm animals and poultry which consume it. The remaining 4,000,000 cwt. of offal is, to a large extent, lost in domestic and fishmongers' waste.

The dietary significance of the edible portion is primarily as a source of protein. Demersal fish are mainly non-fatty, and the chief individual species, cod and haddock, contain less than 1 per cent. of fat in the flesh. Those species like plaice and halibut which have rather fattier flesh with about 4 per cent. fat are only a small proportion of the total, and the dietary significance of their fat content can be ignored in a broad survey. The percentage of protein in fish, if determined as total nitrogen $\times 6.25$ (Chatfield and Adams, 1940), varies from about 16.5 to 20.0 or more, with an average of about 17 . This value is rather too high, due to inclusion of non-protein nitrogen, which may be a serious factor in such fish as skate and dogfish, which contain relatively large proportions of urea. McCance and Shipp (1933) estimate protein by subtracting the extractive nitrogen from the total nitrogen, and multiplying the result by $6 \cdot 25$; the values thus obtained approximate on the average to 16 per cent., a figure in good agreement with those obtained at the Torry Research Station, which are based on the total nitrogen precipitable with trichloro-acetic acid. By any method of estimation it will be found that the variations in protein content which occur within any particular species are greater than between the average values for the common species. It thus seems fair to take this average value of 16 per cent. for all white fish and, on this basis, the edible portion of demersal fish furnished in 1938 a total of 976,800 cwt. of protein. If the total population is taken as $46,000,000$, an average supply of $2 \cdot 4 \mathrm{lb}$. of protein per head per year is thus obtained.

In addition to the demersal fish, there are the pelagic or free swimming fish, such as herrings, mackerel and sprats, caught in the waters near the surface. The landings of pelagic fish for 1938 are shown in Table 2 from which it can be seen that herrings accounted for 94 per cent. of the total.

TABLE 2

Total Landings of Pelagic Fish for 1938

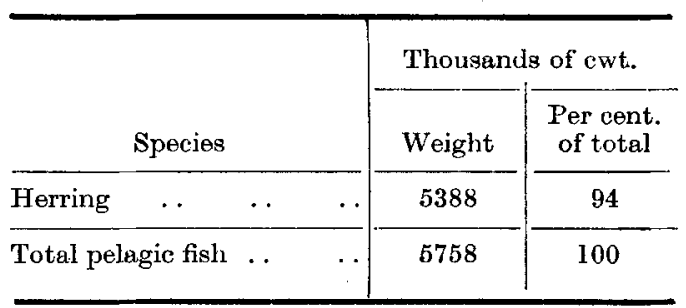

The contribution of the 1938 catch of pelagic fish to the British diet represents a potential one for the future, since, in contrast with exports of demersal fish, the peace time exports of herrings were far in excess of imports. For 1938, the imports of fresh herrings totalled 358,464 cwt., and the exports, in the form of cured herrings, totalled 1,881,608 cwt., leaving a net loss of about $1,500,000 \mathrm{cwt}$,, out of the $5,388,000 \mathrm{cwt}$. of British landing.

voL. 1, 1944] 
In considering the dietary significance of pelagic fish, it is safe to take the herring as a guide for three reasons, because it constitutes the overwhelming proportion of the total, because the various species resemble each other closely in composition, all being fatty fish, and because the members of this group, in contrast with demersal fish, show wide seasonal variations in composition, rendering futile any attempt at more than a rough estimate of average composition. Fortunately, it has been found that the seasonal variations affect almost entirely the ratio of fat to water (Lovert and Wood, 1937), whilst protein remains within the same range as that for demersal fish, with the same average value of about 16 per cent. The seasonal variations in fat cover a normal range of from about 3 to over 20 per cent., with extreme examples well outside both limits. It is, perhaps, surprising to find that such large variations are entirely balanced by variations in an inverse direction of the water content. The lower fat values are found during winter and early spring, and the bigher values during summer and autumn. Since most of our herrings are caught during summer and autumn, it is suggested that an average value of 15 per cent. of fat may be taken in reckoning the dietary contribution of herring and of total pelagic fish.

The factor for waste in pelagic fish, with the commercial fillet again taken as representing the part normally eaten, appears to be about 45 per cent. (Chatfield and Adams, 1940; Torry Research Station, 2), which is distinctly less than for demersal fish. With pelagic fish, however, most of this waste is domestic, so that only a small proportion, mainly of viscera, reaches the fish meal manufacturer.

On the basis of the 1938 catch and of the above figures, the total contribution which pelagic fish could make to the British diet is about 506,700 cwt. of protein and $475,100 \mathrm{cwt}$. of fat, or $1 \cdot 2 \mathrm{lb}$. per head per year for each.

The total potential contribution of the British fishing fleet to the national diet, at the 1938 level of catch, would thus be $3.7 \mathrm{lb}$. of protein per head per year. In addition there would be $1.2 \mathrm{lb}$. of fat per head per year consumed directly, to which should be added the potential production of fish liver oils. Commercial cod liver oil is made from the livers of mixed species of white fish, and the average liver weight of such fish is about 5 per cent. of the bodyweight. If the livers are worked up by the steaming process, as the majority probably are, the average yield of oil will be about 50 per cent. of the weight of the livers. On this basis, the total potential production of oil from white fish livers in 1938 was 19,000 ton, or $0.9 \mathrm{lb}$. per head per year. This makes a total fish fat production of $2 \cdot 1 \mathrm{lb}$. per head per year.

In addition to providing this protein and fat, fish are important as a source of vitamins $A$ and $D$. So far as vitamin $A$ is concemed, the direct contribution of fish flesh may probably be ignored, as the eels are the only species with a notable concentration of this vitamin in the flesh, and they constitute an insignificant fraction of the total landings. For vitamin D, the herring must be taken into account. Herring flesh contains varying amounts of this vitamin but, from the published data, the flesh oil appears to contain about the same amount of vitamin D as cod liver oil, on the average $100 \mathrm{I} . \mathrm{U}$. per g. If the total possible amount of cod liver oil and of the oil in the edible portion of herring and other pelagic fish is included, 
and if the average values for vitamins $A$ and $D$ in cod liver oil are taken as being 1000 and 100 I.U. per g., respectively, supplies of 1154 and 261 I.U. per head per day of vitamins $A$ and $D$, respectively, are arrived at on the basis of the 1938 landings. In this calculation no allowance has been made for any diversion of oil for veterinary purposes.

The contribution of highly potent oils, of which halibut liver oil is the only one produced in any quantity from our domestic fisheries, can furnish only insignificant amounts of vitamin $A$ and $D$ per head of the whole population. The total landings of halibut for 1938 were $95,855 \mathrm{cwt}$. Halibut have a relatively small liver, about 2.5 per cent. of the total weight, and the oil content is low, about 20 per cent. Average potencies for halibut liver oil may be taken as about 58,000 I.U. per g. for vitamin A and 2500 I.U. per g. for vitamin D (Evers, Jones and Smith, 1936). These figures give values of 84 and 3.6 I.U. per head per day for vitamins $A$ and $\mathrm{D}$.

There is one other industry which is referred to as a fishery, and that is the whaling industry. The British whale fisheries in 1938 brought home 99,924 tons of oil and, in addition, 75,578 tons of foreign caught whale oil was imported. These 99,924 tons give about $4.9 \mathrm{lb}$. per head per annum. Whale livers are of commercial value as a source of vitamin $\hat{A}$, but their content of vitamin $D$ is so low that it can be neglected. If $500 \mathrm{~kg}$. is taken as the average weight of a whale liver, with an oil content of 3 per cent., and an average value of 70,000 I.U. of vitamin A per g. oil, and if $10 ; 000$ whales per annum is the average catch for British expeditions (Bomskov and Unger, 1938; Torry Research Station, 1), a value of 624 I.U. vitamin A per head per day is obtained. Whilst this is only a very rough approximation, probably much less accurate than the figures given for cod liver oil, it is believed that it does give a true idea of the order of magnitude of this supply of vitamin A.

The above results for the average amounts available to the individual are summarized in Table 3. The values given in brackets are based roughly on the actual amounts of British caught herrings consumed in this country, when an allowance is made for the amounts of herrings exported in 1938 and for no imports. As regards vitamins $A$ and $D$, it is uncertain how much of the potential production is consumed by the human population at home, as distinct from that given to animals. This country normally exports far more cod liver oil than it imports.

TABLE 3

Average Total Contributions of Sea foods to the Diet of the British INdividual

\begin{tabular}{llllc}
\hline & & \multicolumn{3}{c}{$\begin{array}{c}\text { Estimated Supply } \\
\text { (Pounds per head per annum) }\end{array}$} \\
Fish (edible portion) & & $\ldots$ & $22 \cdot 6(20 \cdot 1)^{*}$ \\
Protein & $\ldots$ & $\ldots$ & $\ldots$ & $3 \cdot 6(3 \cdot 2)$ \\
Fat & $\ldots$ & $\ldots$ & $\ldots$ & $7 \cdot 0(6 \cdot 6)$ \\
& & & & (I.U. per head daily) \\
Vitamin A & $\ldots$ & $\ldots$ & $\ldots$ & 1862 \\
Vitamin D & $\ldots$ & $\ldots$ & $\ldots$ & $265(218)$ \\
\hline
\end{tabular}

* Values in brackets are based on the actual amount of British caught herrings consumed in this country in 1938.

voL. 1,1944$]$ 
After the pre-war production has been examined, it is necessary to ask what are the chances of increasing any or all of these supplies. It seems certain that the whaling industry cannot be appreciably increased since, without the present restrictive legislation, the industry would have already collapsed through over catching. The catches of demersal fish have shown a more or less steady increase up to 1937, due to the extension of fishing to more and more distant waters. It is probable that no further new ground remains to be exploited by British vessels and, judging by past experience in localities which have been intensively fished, there is a very definite limit to the extent to which any area can be fished without suffering progressive depletion of stocks. It seems likely, therefore, that there is no prospect of any appreciable increase in the landings of demersal fish over those for 1938 if, indeed, it proves possible to maintain this level after the remote northern waters have been steadily exploited for a few years.

In the case of pelagic fish, however, as represented almost exclusively by herring, there has been an artificial restriction of the industry, due to a loss of export markets. We have never consumed all of our annual herring catch at home and, as already mentioned, even the reduced exports of 1938 amounted to nearly 2,000,000 cwt. It might well be possible to expand the herring fishing industry to the 1913 level, which was about the last year of unrestricted fishing. The catch for 1913 was $11,762,748$ cwt., more than twice the 1938 catch. There have not been the same definite danger signs of overfishing for herring as for demersal fish and, unless there should be a large coneurrent expansion of herring fishing by foreign vessels in the waters adjacent to the British Isles, there seems no reason why there could not be a return to the 1913 level of eatching, provided that there was a demand by consumers. If all this fish were consumed at home, it would represent an average of three fish per person per fortnight (MacLennan, 1934).

To make the best possible use of our fish and to reduce the proportion condemned as too stale for human food, the introduction of freezing and cold storage on board our longer distance trawlers appears to be a necessary future development. Much could be done to improve the quality of herrings by the use of ice. If our home consumption of herrings other than salted herrings, which are not popular here, is to be greatly increased, cold storage will be necessary to deal satisfactorily with periods of seasonal. abundance and scarcity.

The author wishes to express his thanks to the Department of Scientific and Industrial Research for permission to give this paper and to quote results obtained as part of the programme of the Food Investigation Board.

\section{REFERENCES}

Bomskov, C. and Unger, F. (1938). F'ette u. Seifen, 45, 90.

Chatfield, C. and Adams, G. (1940). Circ. U.S. Dep. Agric. no. 549.

Evers, N., Jones, A. G. and Smith, W. (1936). Analyst, 61, 7.

Lovern, J. A. and Wood, H. (1937). J. Mar. biol. Ass. U.K. 22, 281.

MacLennan, K. (1934). J. State Med. 42, 588.

McCance, R. A. and Shipp, H. L. (1933). Spec. Rep. Ser, med. Res. Coun., Lond., no. 187.

Monssen, A. (1930). Årsberetn. Vedkommende.Norges Fiskier, no. 3, 27.

Torry Research Station: (1) Collected data and private reports. (2) Trade reports. (3) Unpublished observations. 


\section{Crops}

\section{Mr. A. R. Wannop (North of Scotland College of Agriculture, Aberdeen)}

To provide Stiebeling's adequate diet at moderate cost certain increases and decreases in the direct human consumption of crops would be necessary. Figures are given in the table circulated by the other speakers.

Potatoes and other vegetables could and should be very largely home produced. It is doubtful if Stiebeling's standard for the consumption of potatoes, involving for this country a reduction of the crop by 21 per cent., is advisable, and plans should be based on a consumption similar to that before the war. In 1938 approximately 700,000 and 250,000 acres were under potatoes and other vegetables, respectively, and approximately $1,100,000$ acres could supply an adequate standard of both. This would involve some reduction in imports, but an organized food policy would probably in any case reduce these in consequence of an increased consumption in the countries of origin.

Fruit. A very large increase in consumption amounting to 168 per cent. would be required. The present acreage of approximately 65,000 for soft fruits and 260,000 for orchards would need to be increased to a combined total of about 850,000 . Production of apples could be greatly increased, that of soft fruits would be more limited until control of pests and diseases and conditions of storage had been better developed. Certain fruits are unsuitable for home production and would have to be imported. To reduce imports, still greater expansion would be necessary.

Sugar. More sugar could be produced in the United Kingdom, but it is doubtful if this would be a wise policy to adopt. Without special financial assistance production could not have reached the 336,000 acres of beet grown in 1938 .

Flour and cereals. Any attempt to produce even a large proportion of the cereals and flour required for human consumption would be unwise and contrary to international commitments. Home production of cereals should be such as is necessary for the maintenance of a healthy, balanced agriculture.

General. Out of a pre-war acreage of about $31,500,000$ acres of crops and grass, about $9,000,000$ were under tillage crops. It is estimated that at present tillage crops have increased by about 50 per cent., but a suitable post-war figure would be $12,000,000$ acres. Of this, about 900,000 should be under fruit, and about $1,100,000$ under potatoes and other vegetables. A further 2,000,000 acres would be required for root and forage crops for livestock and for bare fallow, leaving 8,000,000 acres for cereals. Production from the latter should reduce the amount of cereals to be imported for animal feeding.

A better use of grassland would be essential and more home grown protein would be required. Recent research indicates that the best way of obtaining this would be by making grass silage or possibly by drying grass. An extension of the tillage acreage to $12,000,000$ acres would absorb 3,000,000 acres of better grassland, but by better management of the remaining grassland, especially by manuring and reseeding the poorer grassland, the present livestock population could easily be maintained vor. 1,1944$]$ 
on this reduced area, and grass conservation for winter milk production could also be developed. It ought also to be possible to allow for an increase in dairy stock and hens.

Imports. The percentages of these various foodstuffs which were imported before the war were as follows:

$\begin{array}{lrlllll}\text { Potatoes .. } & \ldots & \mathbf{3} & \text { Fruit } & \ldots & \mathbf{7 5} & \text { Cereals and flour } \\ \text { Other vegetables } & \mathbf{3 5} & \text { Sugar } & \ldots & \mathbf{7 7} & \end{array}$

The amounts of potatoes and other vegetables imported should be reduced considerably. The amount of fruit could be reduced to about 50 per cent. The amounts of sugar, cereals and flour to be imported should be determined by international commitments, but for some time a reduction is likely to be experienced.

\section{Discussion}

Dr. I. Leitch (Imperial Bureau of Animal Nutrition, Bucksburn, Aberdeen) opened the discussion, summarizing the various papers briefly. She paid particular attention to Dr. Wright's suggestion that, in this country, we should concentrate on production from milk of cheese instead of butter, and rely for our fats on imported vegetable oils. She felt that this might affect human nutrition adversely both here and in the countries of origin of the vegetable oils. In any case whatever butter was eaten must be budgeted for as milk.

Dr. N. C. Wright (Hannah Dairy Research Institute, Kirkhill, Ayr) said that he proposed that we import only the oil to make margarine, leaving the oil seed residues in the countries of origin to feed cattle and thus increase milk production in tropical countries.

Dr. R. P. Cook (Department of Physiology, University College, Dundee) thought that the use of hydrogenated fats in the form of margarine might lead to a deficiency of essential fatty acids in human diets. Other speakers claimed that there was no such danger; the total requirement of essential fatty acids was small and there would be still a sufficiency of essential fatty acids in other foods were butter entirely replaced by margarine in human diets.

The difficulty of providing an adequate cheap supply of vegetables all the year round was discussed by various speakers. Dr. A. Lyall (Royal Infirmary, Aberdeen) stressed the need for a steady supply of vegetables for therapeutic purposes, and Surgeon Commander C. C. Ungley (Naval Auxiliary Hospital) pointed out that potatoes and turnips were at present the most important natural sources of vitamin $\mathrm{C}$ in winter time.

Mr. A. R. Wannop said that fresh vegetables could be produced at all seasons; small demand on the part of the public and defective marketing were the chief causes of the poor and dear supply of vegetables in winter time. Other speakers, at this time and also later, commented on the poor marketing of vegetables in this country and also blamed the housewife for lack of enterprise in use of vegetables. The failure of domestic science teaching in schools, and elsewhere, to create a demand for vegetables was noted. Miss G. L. Stuart (School of Domestic Science, 
Aberdeen) pointed out that domestic science teaching was fruitless without willingness on the part of the public to put the teaching into operation in the home.

Dr. G. A. Reay (Torry Research Station, Aberdeen) advocated drying, freezing or canning of vegetables on a much greater scale than at present to overcome the reluctance of the housewife to use such food.

Various speakers commented on the poor public demand for cheese in Britain. Greater skill in the making of cheese in this country, better methods of distribution, and education of the public were stressed as highly desirable.

Dr. I. Leitch pointed out that, in the United States of America, it might be necessary, in order to give all Americans a liberal diet, to transfer land from growing cotton and tobacco to growing food crops. Export surpluses might disappear. Mr. A. R. Wannop said that, although it was possible for land to produce cereals at a low level almost indefinitely, such a procedure was not desirable. Rotation of crops, with vegetable production fitted into a scheme of mixed farming, was better for the land and for the community but required more labour on the land. Dr. N. C. Wright said that, in India, cotton had been grown successfully in rotation with food crops.

The importance of the proper care of grass lands, and the success of "grass cropping" was emphasized by several speakers. Grass storage, however, was difficult and expensive. 